\title{
Plusaetis sibynus (Siphonaptera: Ceratophyllidae): a new record of flea on Didelphis virginiana, with a checklist of fleas for this host Plusaetis sibynus (Siphonaptera: Ceratophyllidae): nuevo reporte
de pulga en Didelphis virginiana, con lista de pulgas para este
hospedero
}

\author{
Yury GlebskiY ${ }^{1,2 *}$, Roxana Acosta-GutiérRez ${ }^{3}$, and Zenón Cano-Santana
}

'Laboratorio de Interacciones y Procesos Ecológicos, Facultad de Ciencias, Universidad Nacional Autónoma de México, Ciudad Universitaria, Coyoacán, C. P. 04510. Ciudad de México, México. E-mail: agloti@ciencias.unam.mx (YG); zcs@ciencias.unam.mx (ZC-S).

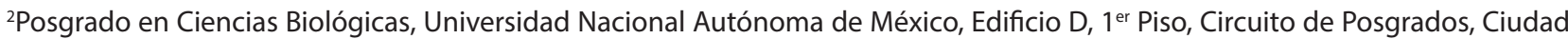
Universitaria, Coyoacán, C. P. 04510. Ciudad de México, México.

${ }^{3}$ Museo de Zoología "Alfonso L. Herrera", Facultad de Ciencias, Universidad Nacional Autónoma de México, Ciudad Universitaria, Coyoacán, C. P. 04510. Ciudad de México, México. E-mail: roxana a2003@yahoo.com.mx (RA-G).

*Corresponding author

Virginia opossums (Didelphis virginiana) are hosts to a variety of fleas that can be important vectors for diseases, including some zoonosis; therefore, it is important to generate knowledge about the fleas that parasite this animal. We present the list of all fleas found on opossums, and the discovery of a species that has not been previously found on D. virginiana, neither on other marsupials. We collected fleas from Virginia opossums in the urban area of México City, México, and performed a bibliographical search to determine which species of fleas were previously recorded. We found previous records of 26 species of fleas on opossums, and we added the flea species Plusaetis sibynus to this list. Plusaetis sibynus is a common flea of rodents (mainly Peromyscus and Neotoma), representing a potential vector of diseases from these rodents to the opossum and human populations. Further research is needed to assess the role of this flea as a vector of zoonotic diseases.

Key words: Diseases; new world marsupials; Plusaetis sibynus; opossum; zoonosis.

El tlacuache de Virginia (Didelphis virginiana) es hospedero para una variedad de pulgas que pueden ser importantes vectores para la transmisión de enfermedades, incluyendo zoonosis; por lo tanto, es importante generar conocimiento sobre las pulgas que parasitan a este animal. En este trabajo, presentamos la lista de pulgas que parasitan a los tlacuaches, con la adición de una especie que no ha sido registrada previamente en D. virginiana, ni en otros marsupiales. Colectamos pulgas de tlacuaches de Virginia en el área urbana de la Ciudad de México, México, y también realizamos una búsqueda bibliográfica para determinar las especies de pulgas reportadas previamente. Encontramos registros de 26 especies de pulgas en los tlacuaches y añadimos a esta lista la especie de pulga Plusaetis sibynus. Plusaetis sibynus es una pulga común en roedores (principalmente Peromyscus y Neotoma), por lo que representa un vector potencial para la transmisión de enfermedades de estos roedores a los tlacuaches, y posteriormente a las poblaciones humanas. Se requieren más estudios para determinar el papel de esta pulga como vector de enfermedades zoonóticas.

Palabras clave: Enfermedades; marsupiales del Nuevo Mundo; Plusaetis sibynus; tlacuaches, zoonosis.

๑) 2021 Asociación Mexicana de Mastozoología, www.mastozoologiamexicana.org

Fleas (Siphonaptera), among other parasites, are important vectors that transmit diseases (Krueger et al. 2016; Dean et al. 2018), both between individuals of the same species and between different species, including the transmission of significant zoonotic diseases like the bubonic plague (Dean et al. 2018). However, flea species have a certain range of host species on which they can inhabit, and between which they are likely to transmit the diseases. In this case, we studied fleas parasitizing the Virginia opossum, Didelphis virginiana Kerr, 1792, a very common and widely distributed marsupial (McManus 1974), adapted well to the urban environments (Wright et al. 2012). Such characteristics point out to the Virginia opossum as an important host of parasites known as vectors of zoonotic diseases, so specific studies are needed. Previous studies show that opossums are vectors of several zoonotic diseases: leptospirosis, salmonellosis (Ruiz-Piña et al. 2002), toxoplasmosis (Torres-Castro et al. 2016), among others, including microorganisms transmitted by fleas, most remarkable Rickettsia (Krueger et al. 2016). Therefore, this work aims to report a new species of flea found on a Virginia opossum and offer a checklist of fleas reported previously on this host species.

From January to March 2020, we live-trapped Virginia opossums in six locations in southern parts of the urban area of México City, México (Figure 1), using pitfall traps consisting of plastic containers $75 \mathrm{~cm}$ in height and $50 \mathrm{~cm}$ 


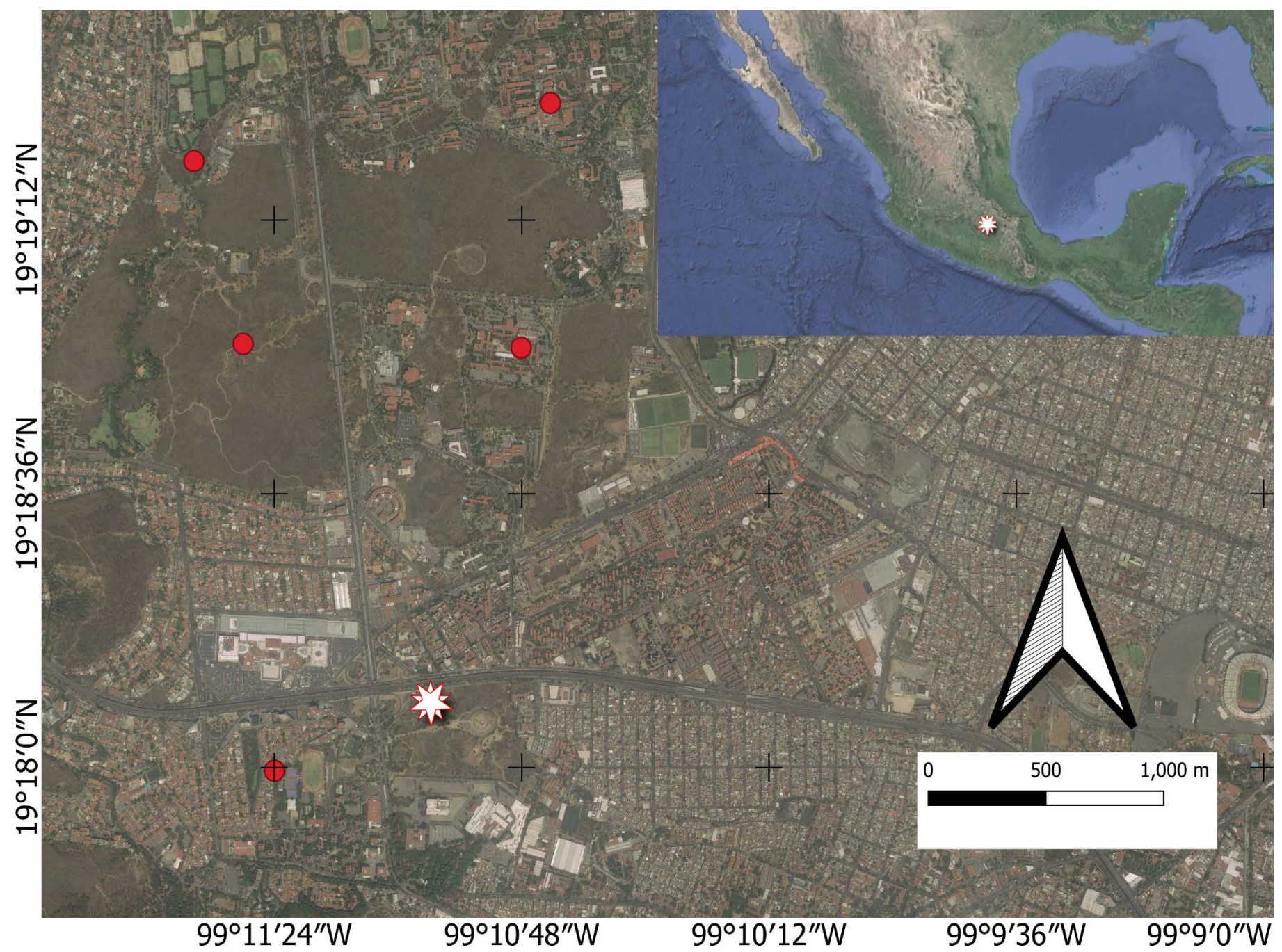

Figure 1. Map of the study sites (red dots). The white star shows the location where Plusaetis sibynus was found, notice that this location is surrounded by urban areas.

in diameter. We made a total effort of 144 trap-nights, and fleas were collected from Virginia opossums and stored in vials with $70 \%$ ethanol and labeled (all captured opossums were released). Fleas were identified following Traub (1950), Acosta and Morrone (2003), and SalcedaSánchez (2004).

Complementarily, we performed a bibliographical search of parasites hosted by the Virginia opossum, using the following terms: "pulga + Didelphis virginiana", "flea + Didelphis virginiana", and "Siphonaptera + Didelphis virginiana".

We captured a total of 32 specimens of Virginia opossums and collected a total of 18 fleas on 12 individuals. Out of the total, 17 fleas were identified as Ctenocephalides felis (Bouché, 1835; Pulicidae) by the presence of the genal comb horizontal, usually extending entire length of lower margin of head and located below of eye, the genal spines are equal, and has a low sloping forehead (SalcedaSánchez 2004), and 1 male individual of Plusaetis sibynus (Jordan, 1925) (Ceratophyllidae; Figure 2), by an occiput (in post antennal region) with 2 or more longish bristles behind base of antennal groove and 3 or more in the mid- dle, arranged in rows; eighth tergum with 5 or 6 median and 2 ventral lateral bristles; and the eighth sternum (Traub 1950). This representing the first time $P$. sibynus is found on a Virginia opossum, or any other marsupial.

In the bibliographical search, we found 26 species of fleas belonging to 18 genera, and 5 families, which were previously reported on the Virginia opossum across 4 countries (Table 1). Plusaetis sibynus represents species number 27 in the checklist.

Before this work, P. sibynus was only reported for rodent species of the genera Peromyscus, Neotoma, and Reithrodontomys (Acosta 2005; Montiel et al. 2019). This report unveils a possible vector of zoonotic diseases between the rodents and opossums, and it is especially important since the host rodent genera are common in natural areas (or their remnants, such as parks inside urban areas), but not in the urbanized areas (Bolger et al. 1997; Harris et al. 2016), so their contact with humans is limited, yet opossums can occur in both (Wright et al. 2012). Therefore, hypothetically, the Virginia opossums could act as a bridge for microorganisms of public health concern, between the field rodents and the urban human populations. However, 
further studies are needed to truly assess the potential of disease transmission via this vector parasitizing Virginia opossums, and the identity of such diseases, especially considering that other species of the genus Plusaetis have proven to carry zoonotic bacteria like Bartonella (SánchezMontes et al. 2019).

When analyzing the historical records of fleas on Virginia opossums (Table 1), we found that the most common flea in geographical range, number of reports, and abundance, is the cat flea, Ctenocephalides felis (Hernández-Camacho et al. 2014; Krueger et al. 2016; this study). This finding is relevant since it is a very common flea that can be hosted by many species, including domestic animals (Maina et al. 2016); therefore, it can move diseases even closer to human populations. We conclude that the Virginia opossum has an important potential for spreading diseases, and the vectors connecting this species to other animals should be carefully studied.

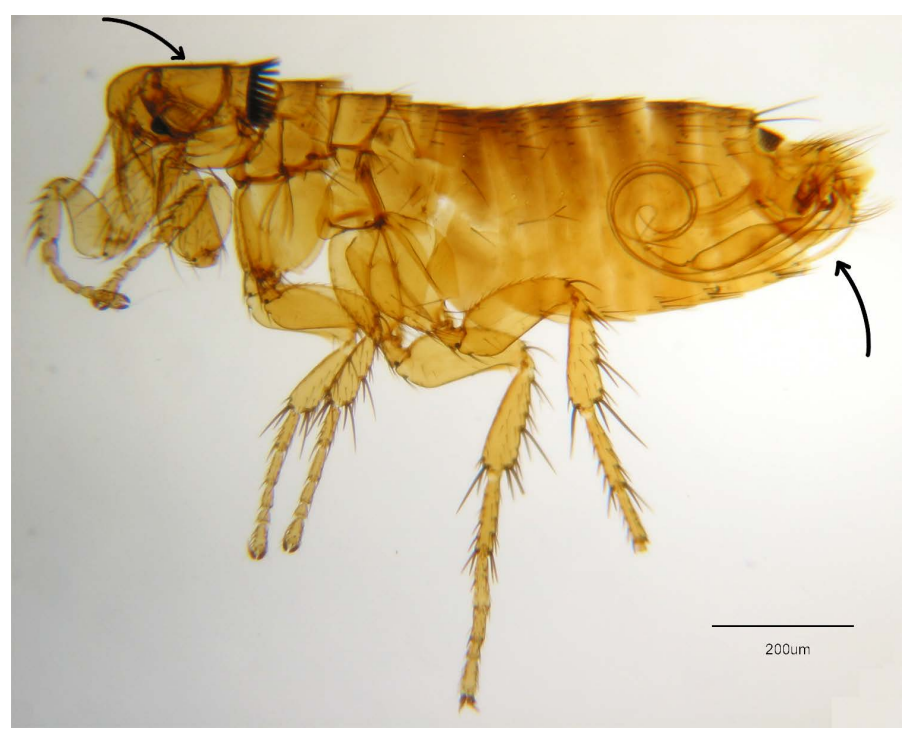

Figure 2. Photograph of the specimen of Plusaetis sibynus (male) found on Didelphis virginiana. Occiput, upper arrow. Sternum VIII, right arrow.

Table 1. List of families and flea species on the Virginia opossum, Didelphis virginiana, and the countries where they are reported.

\begin{tabular}{|c|c|c|}
\hline Species & Country & Reference \\
\hline \multicolumn{3}{|l|}{ Ceratophyllidae } \\
\hline Nosopsyllus fasciatus (Bosc, 1800) & USA & Elbel 1951 \\
\hline Orchopeas howardi (Baker, 1895) & USA & Mohr and Morlan 1959 \\
\hline Orchopeas leucopus (Baker, 1904) & USA & Whitaker et al. 1976 \\
\hline Orchopeas wickhami (Baker, 1895) & USA & Shaftesbury 1934 \\
\hline Oropsylla arctomys (Baker, 1904) & USA & Holland and Benton 1968 \\
\hline Plusaetis sibynus (Jordan, 1925) & México & This study \\
\hline \multicolumn{3}{|l|}{ Hystrichopsyllidae } \\
\hline Corrodopsylla hamiltoni (Traub, 1944) & USA & Schiefer and Lancaster 1970 \\
\hline Ctenophthalmus pseudagyrtes Baker, 1904 & USA & Whitaker et al. 1976 \\
\hline Epitedia neotomae Jameson, 1946 & USA & McAllister et al. 2017 \\
\hline \multicolumn{3}{|l|}{ Leptopsyllidae } \\
\hline Ctenopsyllus catatina (Jordan 1928) & USA & Shaftesbury 1934 \\
\hline Leptopsylla segnis (Schonherr, 1811) & USA & Mohr and Morlan 1959 \\
\hline Odontopsyllus multispinosus (Baker, 1898) & USA & Mohr and Morlan 1959 \\
\hline \multicolumn{3}{|l|}{ Pulicidae } \\
\hline Cediopsylla simplex (Baker, 1895) & USA & Whitaker et al. 1976 \\
\hline Ctenocephalides canis (Curtis, 1826) & USA & Whitaker et al. 1976 \\
\hline Ctenocephalides felis (Bouche, 1835) & Guatemala, México, USA & Mohr and Morlan 1959; Villalobos-Cuevas et al. 2016; Escobar et al. 2011; this study \\
\hline Echidnophaga gallinacea (Westwood, 1875) & USA & Mohr and Morlan 1959 \\
\hline Hoplopsyllus glacialis (Taschenberg, 1880) & México, USA & Schiefer and Lancaster 1970; Hernández-Camacho et al. 2014 \\
\hline Pulex irritans Linnaeus, 1759 & México, USA & Mohr and Morlan 1959; Villalobos-Cuevas et al. 2016 \\
\hline Pulex porcinus Jordan \& Rothschild, 1924 & México & Villalobos-Cuevas et al. 2016 \\
\hline Pulex simulans Baker, 1895 & México, USA & Wilson and Bishop 1966 \\
\hline Xenopsylla cheopis (Rothschild, 1903) & USA & Mohr and Morlan 1959 \\
\hline \multicolumn{3}{|l|}{ Rhopalopsyllidae } \\
\hline Polygenis gwyni (C. Fox, 1914) & USA & McAllister et al. 2017 \\
\hline Polygenis martinezbaezi Vargas, 1951 & México & Hernández-Camacho et al. 2014 \\
\hline Rhopalopsyllus australis (Rothschild, 1904) & México & Villalobos-Cuevas et al. 2016 \\
\hline Rhopalopsyllus coxi Eads, 1946 & USA & Randolph and Eads 1946 \\
\hline Rhopalopsyllus lugubris Jordan \& Rothschild, 1908 & Costa Rica & Durden and Campbell 2016 \\
\hline Chaetopsylla lotoris (Stewart, 1926) & USA & Whitaker et al. 1976 \\
\hline
\end{tabular}




\section{Acknowledgements}

We are thankful to I. Castellanos-Vargas and M. Guzmán-Torres for technical support, and to E. G. Vázquez-Domínguez, V. M. Sánchez-Cordero, and two anonymous reviewers for their comments. Also, to the teams of SEREPSA (S. CramHeydrich), Cuicuilco Archeological Zone (R. López Valenzuela), Villa Olímpica Sports Center (M. Barrera-Rangel), and Taller de Plantas of the Faculty of Sciences, UNAM (M. E. Muñiz Díaz), for facilitating the permissions and support. This work was possible thanks to a scholarship provided by the CONACYT to YG (CVU 817316), and the PAPIIT grant IN212121 (El efecto de la urbanización sobre el tlacuache Didelphis virginiana en un matorral xerófilo de la Ciudad de México), awarded to ZCS.

\section{Literature cited}

Acosta, R., AND J. Morrone. 2003. Clave ilustrada para la identificación de los taxones supraespecíficos de Siphonaptera de México. Acta Zoológica Mexicana (Nueva Serie) 89:39-53.

Acosta, R. 2005. Relación huésped-parásito en pulgas (Insecta: Siphonaptera) y roedores (Mammalia: Rodentia) del estado de Querétaro, México. Folia Entomológica Mexicana 44:37-47.

Bolger, D. T., A. C. Alberts, R. M. Sauvajot, P. Potenza, C. McCalvin, D. Tran, S. Mazzoni, and M. E. Soulé. 1997. Response of rodents to habitat fragmentation in coastal southern California. Ecological Applications 7:552-563.

Dean, K. R., F. Krauer, L. Walløe, O. C. Lingjaerde, B. Bramanti, N. C. Stenseth, AND B. V. Schmid. 2018. Human ectoparasites and the spread of plague in Europe during the Second Pandemic. Proceedings of the National Academy of Sciences 115:1304-1309.

Durden, L. A., And D. C. Campbell. 2016. Fleas, Lice, and Epifaunistic Pseudoscorpions of Some Native Mammals in Northwestern Costa Rica. Comparative Parasitology 83:240-244.

Elbel, R. E. 1951. Comparative studies on the larvae of certain species of fleas (Siphonaptera). The Journal of Parasitology 37:119-128.

Escobar, L. E., D. Alvarez, F. J. Villatoro, D. Moran, and A. EsteVEz. 2011. Two new flea records from Guatemala: Pulex simulans and Echidnophaga gallinacea (Siphonaptera: Pulicidae), and their host-parasite relationship. Journal of Parasitology and Vector Biology 3:40-43.

Harris, S. E., A. T. Xue, D. Alvarado-Serrano, J. T. Boehm, T. JoSEPH, M. J. HICKERSON, AND J. MunshI-SOUth. 2016. Urbanization shapes the demographic history of a native rodent (the white-footed mouse, Peromyscus leucopus) in New York City. Biology Letters 12:20150983.

Hernández-Camacho, N., S. Vergara-Pineda, R. Acosta-Gutiérrez, AND R. W. Jones. 2014. Nuevos registros de pulgas de tlacuaches Didelphis virginiana (Kerr 1792) en Querétaro, México. Therya 5:347-353.

Holland, G. P., AND A. H. Benton. 1968. Siphonaptera from Pennsylvania mammals. American Midland Naturalist 252-261.

Krueger, L., Y. Bal, S. Bennett, C. Fogarty, S. Sun, M. Kosoy, A. Maina, K. Nelson, E. Platzer, L. Osikowicz, A. L. Richards, F. Shariar, A. Trinidad, and R. Cummings. 2016. Identification of Zoonotic and Vector-borne Infectious Agents Associated with Opossums (Didelphis virginiana) in Residential Neighborhoods of Orange County, California. Proceedings of the Vertebrate Pest Conference 27.

Maina, A. N., C. Fogarty, L. Krueger, K. R. Macaluso, A. Odhiambo, K. Nguyen, C. M. Farris, A. Luce-Fedorow, J. Bennett, S. JiAng, S. Sun, R. F. Cummings, ANd A. L. Richards. 2016. Rickettsial infections among Ctenocephalides felis and host animals during a flea-borne rickettsioses outbreak in Orange County, California. PLoS One 11:e0160604.

McAllister, C. T., L. A. Durden, H. W. Robison, And M. B. Connior. 2017. The fleas (Arthropoda: Insecta: Siphonaptera) of Arkansas. Journal of the Arkansas Academy of Science 71:69-76.

McManus, J. J. 1974. Didelphis virginiana. Mammalian Species 40:1-6.

Mohr, C. O., AND H. B. Morlan. 1959. The nature of parasitism of the opossum by fleas in southwestern Georgia. The Journal of Parasitology 45:233-237.

Montiel, F. A., A. Estrada-Torres, R. Acosta, M. Rubio-Godoy, AND J. Vázquez. 2019. Host species influence on flea (Siphonaptera) infection parameters of terrestrial micromammals in a temperate forest of Mexico. Parasitology 146:670-677.

Randolph, N. M., AND R. B. Eads. 1946. An ectoparasitic survey of mammals from Lavaca County, Texas. Annals of the Entomological Society of America 39:597-601.

Ruiz-Piña, H. A., M. A. Puc-Franco, J. Flores-Abuxapqui, I. Vado-Solis, and M. F. Cardenas-Marrufo. 2002. Isolation of Salmonella enterica and serologic reactivity to Leptospira interrogans in opossums (Didelphis virginiana) from Yucatán, México. Revista do Instituto de Medicina Tropical de São Paulo 44:235-237.

Salceda-Sánchez, B. 2004. Clave para la identificación de adultos de las especies de pulgas (Insecta: Siphonaptera), comunes y de mayor importancia médica en México. Folia Entomológica Mexicana 43:27-41.

Sánchez-Montes, S., M. Y. Cabrera-Garrido, C. A. Ríos-Muñoz, A. Z. Lira-Olguín, R. Acosta-Gutiérrez, M. Mata-Galindo, K. Hernández-Vilchis, D. M. Navarrete-Sotelo, P. ColungaSalas, L. León-Paniagua, and I. Becker. 2019. Detection of Bartonella and Rickettsia in small mammals and their ectoparasites in México. Therya 10:69-79.

Schiefer, B. A., AND J. L. LanCaster JR. 1970. Some Siphonaptera from Arkansas. Journal of the Kansas Entomological Society 43:177-181.

Shaftesbury, A. D. 1934. The Siphonaptera (fleas) of North Carolina, with special reference to sex ratios. Journal of the Elisha Mitchell Scientific Society 49:247-263.

Torres-Castro, M., H. Noh-Pech, R. Puerto-Hernández, B. ReyesHernández, A. Panti-May, S. Hernández-Betancourt, A. YehGorocica, L. Gonzalez-Herrera, J. Zavala-Castro, and F. I. PuerTo. 2016. First molecular evidence of Toxoplasma gondii in opossums (Didelphis virginiana) from Yucatan, Mexico. Open Veterinary Journal 6:57-61.

Traub, R. 1950. Siphonaptera of Central America and Mexico: a morphological study of aedeagus with descriptions of new genera and species. Fieldiana Zoology 1:1-127 + 54 plates.

Villalobos-Cuevas, V. A., M. Weber, M. Lareschi, and R. Acosta. 2016. Pulgas parásitas de mamíferos pequeños y medianos de Calakmul, Campeche, México y nuevos registros de localidades. Revista Mexicana de Biodiversidad 87:1372-1378. 
WhitAKeR, JR., J. O., G. S. Jones, AND R. J. GofF. 1976. Ectoparasites and food habits of the opossum, Didelphis virginiana, in Indiana. Proceedings of the Indiana Academy of Science 86:501-507.

Wilson, N., ANd P. Bishop. 1966. A New Host and Range Extension for Pulex simulans Baker with a Summary of Published Records (Siphonaptera: Pulicidae). American Midland Naturalist 245-248.

WRIGHT, J. D., M. S. BURT, AND V. L. JACKson. 2012. Influences of an urban environment on home range and body mass of Virginia opossums (Didelphis virginiana). Northeastern Naturalist 19:77-86.

Associated editor: Cristian Kraker-Castañeda

Submitted:September 3, 2021; Reviewed: October 8, 2021.

Accepted: October 14, 2021; Published on line: November 3, 2021. 